\title{
An Analysis of Students' Learning Independence in Learning English for Computer Using Google Classroom
}

\author{
Dharmawati \\ Department of Informatics, Faculty of Engineering and Computers, Universitas Harapan Medan, Indonesia \\ dharmawati66@yahoo.com
}

\section{Abstract}

This research aims to know independent learning of English for Compute in using Google Classroom during the COVID-19 pandemic. The method used of this research was elaborating from quantitative and qualitative descriptive. The population was Informatics students in the first semester at Universitas Harapan Medan. Sampling techniques used random sampling with a research sample of 65 students of 1-1 and 1-2 classes. Data collection techniques used triangulation: questionnaires, interviews and observations. The results showed that the average level of student learning independence using google classroom in learning English for Computer during COVID-19 pandemic was very high at the average value of indicators: self-confidence (82.62), sel-discipline (85.51), initiative (82.34), responsibility (84.92), motivation (86.27), then the average indicator of independent learning is 84.33. From these results knows that the scale range of the criteria for the score of the respondent's level of achievement, then the interpretation of learning independence in learning English for computer for Informatics students using Google Classroom during the Covid 19 pandemic is very high.
Keywords

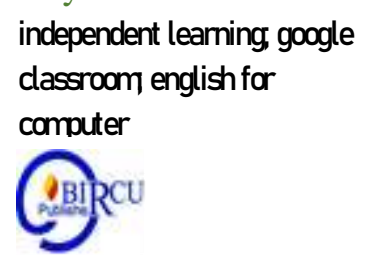

\section{Introduction}

COVID-19 pandemic has changed all aspects of human life. One of them is education aspect, namely changing in teaching and learning process. In facingthis situations, itforces the lecturer to think to teach maximally and efficiently. Distance learning or online can be a solution so that the discussion of the material continues even with online (Silalahi, 2020). The lecturer should motivate students to study harder and adapt to use various media in learning english especially english for computer. During the COVID-19 pandemic, independence in learning is most needed in the teaching and learning process.

Learning proses for university students should not be a problem to force students to study independently, infact it is not easy for the first semester students to adapt in independ learning in university. As a substitution for face-to-face learning process, the learning process is carried out by using google classroom. Google classroom is a free web service, developed by Google which is used as a platform for lecturers and students in distance learning. The use of google classroom aims to facilitate online learning among lecturers and students. Using google classroom in teaching learning process, it will be easier for lecturers to simplify, distribute, and evaluate students' assignments without having face to face. 
English is the international languages. It plays an important role to communicate with the outside world. In fact, English is very important in the world of work (Ramadani, 2021). English is also used by over one billion people who speak English as their second (or additional) language to communicate with other second language users regardless of different culture and linguistic features (Devy, 2016). In Indonesia, English is learned as subject in scool and it is taught from basic school until university. Dharmawati (2019: 1194) stated that English is one of the subjects included in the curriculum in university, but theoritically the proccess of learning English still cannot achieve the results as expected. This can be evidenced by the fact that there are still many students in the university who are still unable to communicate using English even though they have learned it from entering basic school (SD) to university. One aspects need to be mastered by students is the ability to speak English well, both oral and written. Good English skills must master all four language skills (reading, listening, writing and speaking) and vocabulary and grammar.

Teaching English for computer students especially in teaching speaking usually in face-to-face practical learning systems. Teaching and learning process is usually considered as a key point to be mastered by an English lecture, therefore the lecturer just needs to understand the methods and approaches used in teaching speaking. The COVID19 demands lecturers and students must strive to continue to carry out learning with the limited space available. It also forces student learning independence and maximizes the efforts of teachers in studying and preparing learning media that are affordable and easy to use in general for students. The students are forced to study independently.

Several researchers have been conducted related to teach and learn English by using google classroom. Almio and Sri (2019) presented Teachers' Experiences On The Use of google classroom and the finding showed that teachers use google classroom as a tool for managing students' tasks, organizing classroom and accommodating students' interaction. In general, teachers perceived the use of google classroom was very helpful to conduct their virtual classroom. Azhar (2018) investegated the teacher's perception towards google classroom as it is only a facilatation tool, for example for uploading material and writing announcements. Unfortunately, lecturer still see this application ineffective in terms of the lack of user-friendliness. And Ali Buto (2018) also conducted his research on Learning Independence with the results showed that student of Islamic boarding school in North Aceh can be described through several fields, such as students' independence in doing ubuduyah, students' independence education in recitation activities, students' independence education in developing economy through another skill, and independence education in carrying out social activities.

This study conducted on An Analysis of Students' Learning Independence In Learning English for computer using google classroom. it focused on Informatics Students' who learn English for computer by using google classroom during this pandemic era. It was analyzed students' teaching learning process in learning English for computer at speaking, reading, listening and writing activities. 


\section{Review of Literature}

\subsection{Independence Learning}

There are some litrature available for defining the independence learning from some experts. Ali Buto (2018: 225) noted that independence is the ability of individual students to run a life with no dependence on others, so that they can adapt and socialize with the local community well. Yamin in Sudarwo (2018:69) stated that independent learning is an active learning method to develop each individual who is not tied to the presence of learners in a face-to-face class meeting or the presence of other study friends. Independent learning can be interpreted as an attitude that allows a person to do things and act freely either on the encouragement of himself or for his own needs without the help of other parties, as well as to act and think creatively and original (original), initiative and able to influence the environment, have self-confidence and obtain a satisfaction resulting from the efforts he does (Masrun, 1986: 8).

Suryaningsih (2017: 3) cited from Anita Lie that explains that someone who has good learning independence will be consistent, eager to learn and active in learning wherever and whenever, because there is an awareness of the need for learning, discipline, initiative, self-control, responsibility and confident to achieve competence. From some opinions above, it can be concluded that the indicators of independent learning include: self-confidence, self-discipline, initiative, responsibility and motivation.

Based on the indicators of learning independence, it is necessary to compile a detailed descriptor and assess it based on the learning system used, changes to the learning system which was originally a face-to-face system during normal times until it changed to enter this pandemic period, the researcher applied google classroom in teaching learning process on computer students.

\subsection{Google Classroom}

Google Classroom is an Internet-based service provided by Google as an e-learning media. This learning media is designed to help lecturers create and submit assignments to lecturer in making and distributing assignments to students in a paperless manner. google classroom is a product of Google for Education that is very special, because the product has many facilities in it such as giving announcements or assignments, collecting assignments and knowing who has submitted assignments. It is connected connected with youtube, drive, gmail, hangout, and a calendar. There are also many facilities provided by google classroom that will make it easier for lecturers to perform teaching learning activities. The learning process can not only in the classroom, but also outside the classroom because students can learn the material given wherever and whenever by accessing google classroom.

Google classroom is to offer a platform of blended learning in schools in order to simplify creating assignments and getting the grade out to the students in a paperless way (Donald Yates, 2017). google classroom application is very useful for online teaching and learning, and can be obtained for free of charge and can be used on any device. One of the sophistications of this application is that it can be used collaboratively with other groups. There are so many advantages of using google classroom as one of the Learning Management Systems (LSM) (Izenstark \& Leahy, 2015).

There are many activities that you can do with Google Classroom: Making assignments(The thing you, as the lecturer, can do is making assignments. When you create an assignment, you can upload the important file for the students to read or work on. Students will receive e-mail notification of new assignment), making announcements (If 
you have an announcement, you can type in it in the forum), store classroom materials: (You can store many important files for students), and also allowing students to interact with their friends or lecturer (Students can comment on assignments and announcements). The activities of google classroom can be seen on the figure below.

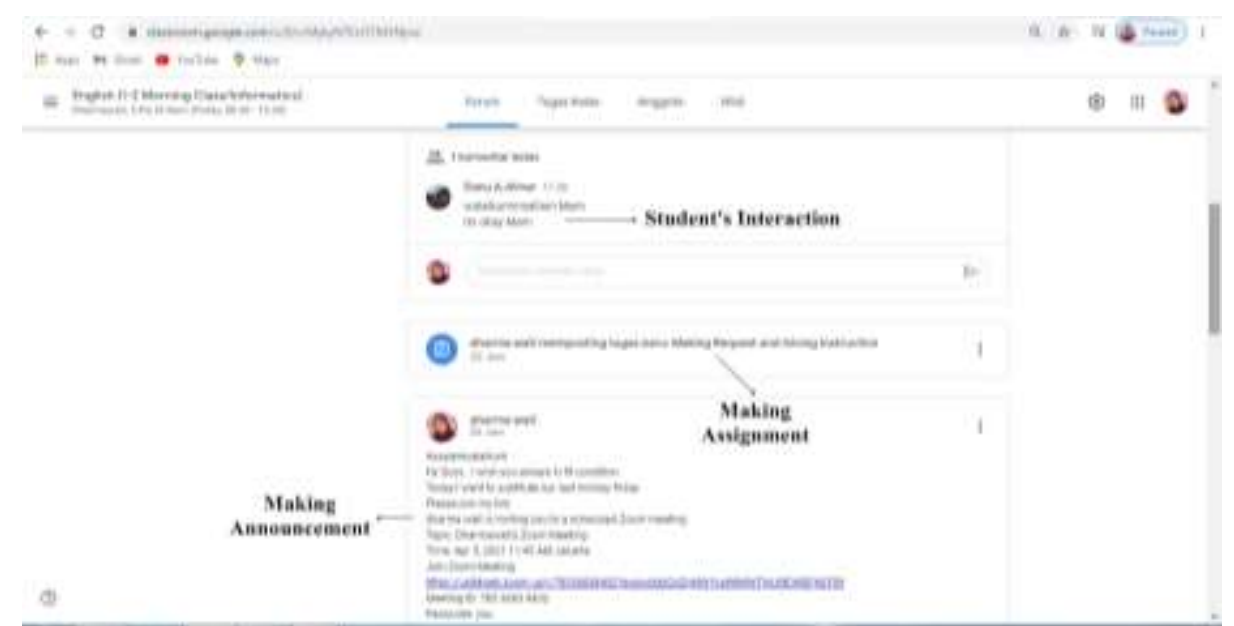

Figure 1. Google Glassroom

\section{Research Methods}

This research used descriptive quantitative and qualitative. It was done at Universitas Harapan Medan and majoring of Informatics. The population was 65 computer students in first semester. Data collection techniques used triangulation: questionnaires, interviews and observations. The research was done for 3 months with online learning by using google classroom. The studens were given post-test and pre-test. The reasearch observed and gave questionaires to students to evaluate students' independent in learning, and also interviewed 10 students randomly. In analyzing the data, the data was elaborated and described by using some steps, they are collecting the data (observation, interviews and dicument), data reduction (selecting data, focusing and make simplifying), data display (presented in table and figure) and conclusion (give meaning, confirming and verifying). The steps can be seen in the figure below.

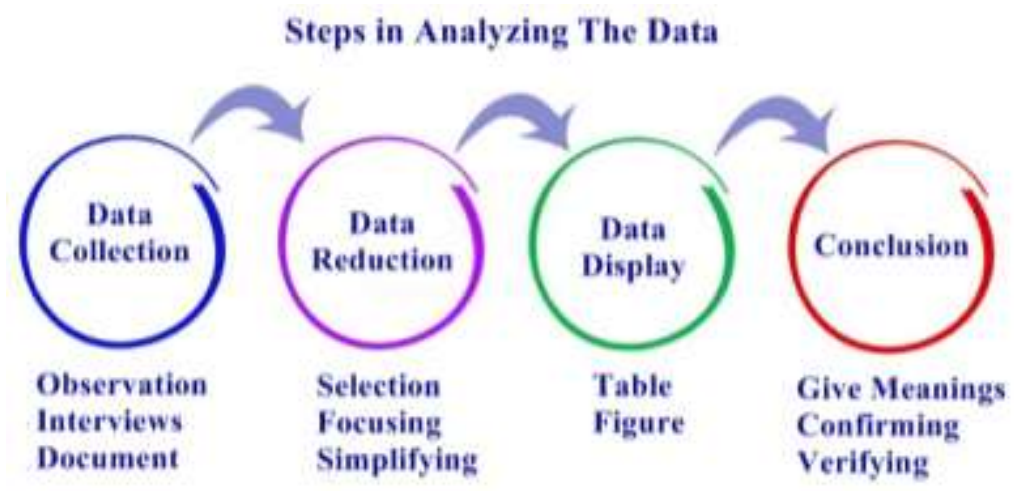

Figure 2. The Steps in Analyzing the Data 


\section{Results and Discussion}

Based on the analysis of students' independence learning, it was resulted from students' independence learning questionnaire in learning English for Computer using Google Classroom. The result can be shown in table 1 below.

Table 1. Students' Independent Learning

\begin{tabular}{|c|l|c|}
\hline No & $\begin{array}{l}\text { Indicator Classification in } \\
\text { Independence Learning }\end{array}$ & Avarage Value \\
\hline $\mathbf{1 .}$ & Self-confident & 82,62 \\
\hline $\mathbf{2 .}$ & Self-discipline & 85,51 \\
\hline $\mathbf{3 .}$ & Initiative & 82,34 \\
\hline $\mathbf{4 .}$ & Responsibility & 84,92 \\
\hline $\mathbf{5 .}$ & Motivation & 86,27 \\
\hline & Average & 84,33 \\
\hline
\end{tabular}

Based on the table above, self-confident is 82,62, self-discipline is 85,51, initiative is 82,34 , responsibility is 84,92 and motivation is 86,27 . And the average score for indicator classification in independence learning is 84,33 (high). Among of indicators, motivation is the higest. It means that students has high motivation in learning English for computer by using google classroom. And the result also can be drawn in the graph of students' independent learning in learning English for computer to explain the everage value clearly.

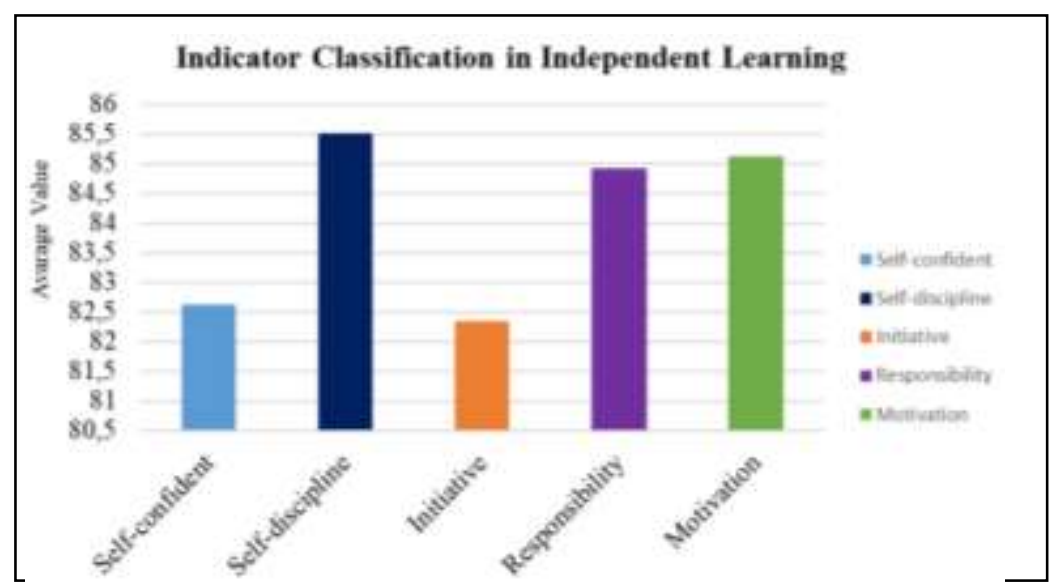

Figure 3. Indicator Classification in Independent Learning

From the data above, it can be translated by using the data range according to Riduwan (2010: 138). It explains the score interpretation criteria for the Respondent Achievement Level are as shown in table 2 below:

Tabel 2. Scale Range of Respondents' Achievement Level

\begin{tabular}{|l|l|l|}
\hline No. & \multicolumn{1}{|c|}{ Number } & Interpretation \\
\hline 1. & $00 \%-20 \%$ & Very Low \\
\hline 2. & $21 \%-40 \%$ & Low \\
\hline 3. & $41 \%-60 \%$ & Average \\
\hline 4. & $61 \%-80 \%$ & High \\
\hline 5. & $81 \%-100 \%$ & Very High \\
\hline
\end{tabular}


Based on the average value of learning independence, the average value on the indicator of self-confidence is 82.61 , It is in the very high interpretation of the scale range. Based on the interview and observation of students, the information was obtained that the level of student confidence in learning to use technology was sufficiently tested. The students who sometimes feel insecure about showing ability at face-to-face meetings, still have the opportunity to demonstrate their abilities through google classroom, such as by writing question, comments or responding to answers in the classroom comments column or when doing assignments of speaking practice in the form of video recordings uploaded on the google classroom page because they have the flexibility of time and ease of interaction in cyberspace and are free to have opinions via the comments column. This is suitable for Bender \& Waller (2014: 37) google classroom is designed to facilitate teacher and student interaction in cyberspace. This application provides an opportunity for teachers to explore their scientific ideas as well as have the flexibility to share knowledge and assignments and open a question and answer room in the classroom. Through this selfconfidence indicator, it shows that the independent learning of computer students in learning English for computer is well-directed using google classroom.

The indicator of self-discipline gets an average score of 85.51 with a very high interpretation, based on students's interview and observations, it is obtained that information although the COVID-19 Pandemic as natural phenomenon is still confortable stay in Indonesia that forces student learning to change in a short time, google classroom can make students adapt with this situation, especially following the question instructions, assignment instructions and discussion instructions described in the google classroom, besides that students can follow the regulations when they are required to submit hardcopy of assignments and meet face-to-face which is determined by the time, as well as when submitting softcopy of assignments as well as discussions according to the given deadline. This is suitable for Rosdiana dkk (2020: 39) which stated that google classroom is proven to be able to improve students' disciplinary attitude in collecting assignments, especially subject assignments with a very positive response and submitting assignments on time.

The Initiative obtained an average score of 82,34 and the Responsibility obtained an average score of 84.92 with a very high interpretation. It was obtained information that students also took the initiative to learn using google classroo, read materials- materials to enrich the understanding of the material. The students are initiative and responsible for doing assignments, discussing and learning to find relevant materials and sources so that these two indicators also play an important role in assessing student learning independence. Motivation indicators get an average score of 86.27 with a very high interpretation, it can be concluded that that students are motivated learning English for computer by using google classroom.

Based on the overall average indicator of independent learning is 84.33 . It can be concluded that based on the scale range of the respondent's level of achievement, then the interpretation of learning independence of students by using google classroom is very strong. The student learning independence is also evaluated by the post-test results as shown in the following figure. 


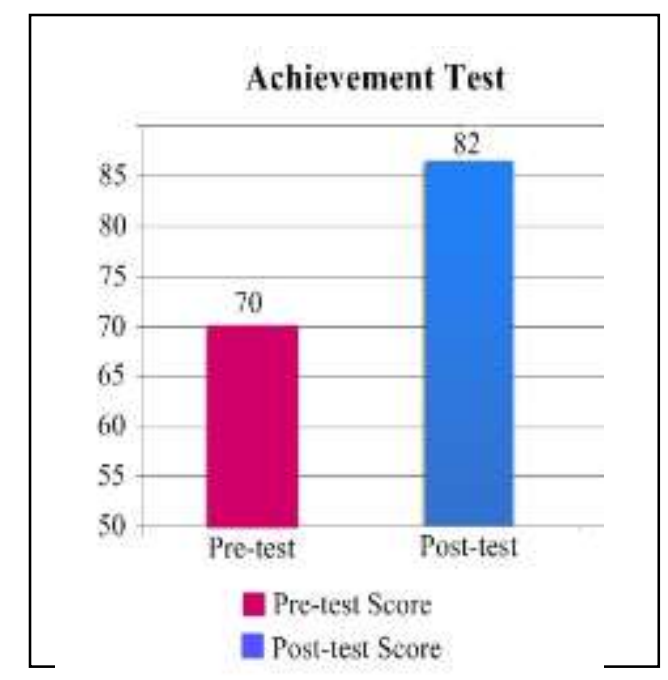

Figure 4. Student's Achievement Test

Based on the figure 1, it is know that the students' achievement test in pre-test, the students got 70 and and in post-test, students got 82 . By having this result, it is concluded that the test results are quite good on the final test results of students. It can be seen that the post-test score is higer than pre-test. It also can prove that COVID-19 causes a lot of concern for students and lecturer to be able to survive in carrying out the learning process using google classroom. The students can read the teaching material given by the lecturer, do the assignment and improve their writing skill by writing comment or question if they don't understand the subject (teaching material), of course they shuld write everything in English. And also the lecturer can create and desain the teaching material by using powerpoint or video presentation.

The use technology such as google classroom motivate students to learn English for computer. It seem that there is no problem for students in using it. Having analyzing the data, the resercher found that the use of google classroom in tyeaching learning process of English for computer is easy to access. And it is shown that the Informatics' students felt excited to learn English for computer using google classroom.

\section{Conclusion}

Based on the expalination from result and discussion of the research, it can be concluded that the google classroom can be an alternative in teaching and learning process in pandemic era. It proves that google classroom can improve students' learning independence. The indicators of learning independence have an average value with very high interpretations, namely: self-confidence $(82,62)$, discipline $(85,51)$, initiative $(83,34)$, responsibility $(84,942)$, motivation $(85,25)$, so that the overall average indicator of independent learning is 84,33. After gining pre-test and post-test it is known that the posttest score is higer than pre-test. By knowing the avarage value, it it shown that students'learning independence in learning English for using google classroom during the COVID-19 Pandemic is generally very high. The Informatics' students felt excited to learn English for computer using google classroom. 


\section{References}

Almio S. A, Sri S. (2019). Teachers' Experiences On The Use of Googl Classroom. English Language and Literature International Conference (ELLiC) Proceedings Vol. 3 No. 1, pp. 172-178

Azhar, K.A. (2018). Effectiveness of Google Classroom: Teachers' perception. Prizren Social Science Journal, vol.2, no. 2, pp. 52-66.

Bender, W., \& Waller, L. (2014). Google Apps. In Cool Tech Tools for Lower Tech Teachers: 20 Tactics for Every Classroom.

Devy, A.G. (2016). The Impact Of English As An International Language On English Language Teaching In Indonesia. Language Circle: Journal lof Language and Literature, Vol X, No. 1.

Dharmawati. (2019). The Use of E-Book In Teaching English For Computer Students. Proceeding: The 1st Multi-Discipinary International conference University Of Asahan, Vol. 1, No.1.

Izenstark, A., \& Leahy, K. L. (2015). Google classroom for librarians: features and opportunities. Library Hi Tech News, 32(9), 1-3.

Nur Alim, dkk. (2019).The Effectiveness Of Google Classroom As An Instructional Media: A Case Of State Islamic Institute Of Kendari, Indonesia. Humanities \& Social Sciences Reviews, Vol 7, No 2, 2019, pp 240-246.

Ramadani, dkk. (2020). The Increasing of Students' English Speaking by Using Community Language Learning (CLL) through Students English Association of LP3I (SEAL) at Politeknik LP3I Medan. Budapest International Research and Critics Institute-Journal (BIRCI-Journal), Volume 3, No 3.

Riduwan. (2010). Belajar Mudah Penelitian. Alfabeta: Bandung.

Sudarwo, R., Yusuf, Y., \& Anfas, A. (2018). Pengaruh Sarana Belajar Dan Motivasi Belajar Terhadap Kemandirian Belajar Mahasiswa (Studi Empirical Pada Mahasiswa Beasiswa Bidikmisi UPBJJ-UT Ternate). Jurnal Pendidikan, 19(2), 68-83.

Sukmawati, Nensia. (2019). The Role of Google Classroom in ELT. International Journal for Educational and Vocational Studies Vol. 1, No. 2, pp. 142-145

Tiodora F Silalahi, Ahmad F.H. (2020). The Application of Cooperative Learning Model during Online Learning in the Pandemic Period. Budapest International Research and Critics Institute-Journal (BIRCI-Journal), Volume 3, No 3.

Zulfikar Ali Buto, Hafifuddin. (2018). Learning Independence of Students at Dayah Muslim School in North Aceh. Budapest International Research and Critics InstituteJournal (BIRCI-Journal) Volume I, No 4, Page: 224-231. 